\title{
Examining the Determinants and Outcomes of Superior Downward Influence Tactics: The Mediating Impact of Role Ambiguity and Subordinates' Competence Level
}

\author{
Kim Lian Lee (Corresponding author) \\ Faculty of Management \& Information Technology, University College Sedaya International \\ No 1, Jalan Menara Gading, UCSI Heights, 56000 Kuala Lumpur, Malaysia \\ E-mail: kllee@ucsi.edu.my \\ Abdul Latif Hj. Salleh \\ Department of Business Policy \& Strategy, Faculty of Business \& Accountancy, \\ University of Malaya, Malaysia \\ E-mail: abdul_latif@um.edu.my
}

\begin{abstract}
This paper examines the antecedents and consequences of superior downward influence tactics in Malaysian companies. The literature review revealed that downward influence tactics are useful but practically challenging. Researchers have identified downward influence tactics such as inspirational appeal, consultation, exchange, pressure, ingratiation, and rational persuasion as commonly used influence tactics by superior to change the behavior of subordinates. The purpose of this paper is to develop a conceptual framework for relating different outcomes of downward influence tactics and the determinants under which such influences are exercised. The outcomes are measured in terms of differences in subordinates' satisfaction with supervision and organizational citizenship behavior when subjected to supervisory downward influence tactics. Understanding different influence tactics affect the outcomes which can provide guidelines for superior in using the suitable influence tactics to increase the organizational citizenship behavior and satisfaction in organizations. Leadership styles, organizational context and mediating variables of role ambiguity and subordinates' competency level were also investigated.
\end{abstract}

Keywords: Downward Influence Tactics, Leadership, Organizational Contexts, Role Ambiguity, Competence, Satisfaction with Supervision, Organizational Citizenship Behavior

\section{Introduction and Objective of the Study}

Influence occurred when an influence leader behavior designed to change a member behavior or attitudes. Although in many occasions the term "influence" is used interchangeably with power and influence tactics, Podsakoff, MacKenzie, Morrman \& Fetter (1990) demonstrated that power alone is not sufficient in explaining a leader's effectiveness in influencing people. Effective leaders must have the skill to recognize when to use different tactics of influence as well as the skill necessary to effectively carry out these influence attempts (Kipnis, Schmidt \& Wilkinson, 1980; Yukl \& Falbe, 1990; Yukl, 1998; Bolino \& Turnley, 2003). A number of researchers have identified categories of proactive behaviors called influence tactics used by superior with different target and objectives (Kipnis, Schmidt \& Wilkinson, 1980; Schriesheim \& Hinkin, 1990; Yukl \& Falbe, 1990; Yukl, Falbe \& Youn, 1993; Yukl \& Tracey, 1992; Ansari \& Kapoor, 1987; Erez \& Rim, 1982; Erez, Rim \& Keider, 1986; Schmidt \& Kipnis, 1984). More recently, there have been several researchers suggested that leadership research needs to focus more on "fundamental" issues, such as influence processes that characterize leader-follower interaction (Bass, 1990; Hollander \& Offermann, 1990; Yukl, 1989). Research has shown that leaders' effectiveness with subordinates depends heavily on their abilities to accomplish things through subordinates (Uyterhoeven 1972; Ruello, 1973). Consequently, the more the leader enters into a set of reciprocal relationships, the more the leader becomes skillful in influencing the subordinates. Moreover, in terms of using downward influence tactics effectively, several empirical studies offer strong support for the idea that the most effective leaders in organizations understand the nature of influence, "what" influence tactics are available to them, and "how" and "when" to use those tactics (Case, Dosier, Murkison \& Keys. 1988; Kaplan, 1986; Kipnis \& Schmidt, 
1988; Mowday, 1978; Schilit \& Locke, 1982; Yukl \& Falbe, 1990). These works seems to infer that influence is important in all human relationships.

There have been few studies done to investigate the superior downward influence tactics in Malaysian work settings with relates to organizational context and leadership as key independent variables and outcomes such as satisfaction with supervision and organizational citizenship behavior. There are also few studies that investigate role ambiguity and subordinates' competence level as mediators. Thus, this research is conducted with the aim of achieving greater understanding of adopting the appropriate influence tactics to enable the superiors to better achieve their objectives in maintaining organizational harmony and unity. Secondly, this research is conducted in Malaysian cultural setting with diverse social and organizational culture. It will be interesting to look at how Malaysian workforce responds to different influence tactics as social behavior is normally implanted and entrenched in the given society. The research is important to address question confronting our industrial society concerned with the issue on how can the skills of managers be enriched so as to make it possible for them to act with greater proficiency when their contributions are from dealing with and through people especially their subordinates. One way of looking into this issue is from the "influence" perspectives of the interpersonal interactions that occur across organizational levels characterized by the phrase "superior-subordinate relationships".

In fact, there is a significant focus of interpersonal relationship researches due to our belief that sound superior-subordinate relationships are important and consistent with humanistic and cooperative work environment sought by contemporary managers. It is also believed that positive interpersonal relationship at workplace is able to increase subordinates' satisfaction with supervision and organization citizenship behavior (OCB). The subordinates with high levels of satisfaction and OCB are more likely to be committed to the organization (William \& Anderson, 1991; Smith, Organ \& Near, 1983). It is worthwhile for the superior to be aware of the existence of multiple sources of influence in work situations and how it promote subordinates' satisfaction with supervision and OCB since negative outcome itself could lead to many organizational dysfunctions such as decline in work performances, absenteeism and high turnover (Lamude, 1994; Motowidlo, 2003). According to Williams and Anderson (1991) superior's tactics of influence with subordinates and subordinates' satisfaction with supervision and OCB are inter-related. Different approach of influence styles can trigger negative consequences, which further increases sensitivity and susceptibility to misunderstanding, which in turn increases dissatisfaction. Thus, prevention of subordinates' negative outcome is important when deals with different influence tactics. This becomes a vicious cycle that many organization leaders need to address downward influence tactics and its consequences more systematically.

On the other hand, there was a substantial amount of the research attention in the context of upward influence directional. Little attention has been given in linking the types of downward influence styles. Knowing how downward influence tactics related to the organizational structure, transformational or transactional leadership, role ambiguity and competence level and its consequences will enable the superior to change or maintain his/her influence tactics to achieve the desirable outcomes. Thus, this study seeks to find out the correlates and outcome of downward influence that would ultimately contribute to the knowledge of organizational management and behavior in this area.

\subsection{Research Questions}

The delineation of research question is to find out the downward influence method employed by superior in the Malaysian companies, what are the correlates and consequences of influence tactics and how it affects subordinates. This research also provides information about the appropriateness and effectiveness of each style as it pertains to specific outcomes (Yukl, Kim \& Falbe, 1996). The key advantage to examine the antecedents and consequences of influence tactics is the maximization of organizational outcomes. This study also sought to answer the following research questions.

Are there any significant differences in subordinates' satisfaction with supervision and organizational citizenship behaviour when subjected to downward influence tactics?

Are there any predictable relationships between organizational variables and downward influence tactics and subordinates' satisfaction with supervision and organizational citizenship behaviour?

Can leadership styles be predictors of the exercise of downward influence tactics and subordinates' satisfaction with supervision and organizational citizenship behaviour?

What is the distribution of the use of influence tactics in Malaysian companies?

Can subordinates' competence level and role ambiguity mediate the relationship between the leadership style and downward influence tactics?

Can subordinates' competence level and role ambiguity mediate the relationship between the organizational context and downward influence tactics? 


\section{Theoretical Framework and Literature Review}

The following sections provide the theoretical foundation and review of the relevant constructs and variables as well as their interactions as shown in Figure 1. The main part discusses the constructs and variables, known relationships between them, theoretical perspective that link downward Influence tactics and those that contribute in explaining the determinants and outcomes of downward influence tactics such as leadership styles and organizational contextual variables (key independent variables), satisfaction with supervision, and organizational citizenship behaviour (key dependent variables) and mediator variables such as role ambiguity and subordinates' competence level.

\subsection{Influence and Influence Tactics}

Kipnis et al. (1980) labels of assertiveness, coalitions, exchange, ingratiation, rationality, and upward appeal represent a broad segment of the influence tactic literature. Schriesheim and Hinkin (1990) replicated the study of Kipnis et al. (1980) and developed new items to measure the same subscales. Yukl and colleagues (Yukl \& Falbe, 1990; Yukl \& Tracey, 1992; Yukl, Falbe \& Youn, 1993; Yukl, Kim \& Falbe, 1996) examined influence tactics from the perspectives of both agent and target, and also extended the work of Kipnis et al. by identifying the additional tactics of inspirational appeal, consultation, legitimating, pressure, and personal appeal. Yukl and Falbe (1990) determined that inspirational appeal and consultation were the most frequently used in downward influence tactics. This conclusion coincides with the research results of Hinkin and Schriesheim (1990), who found that consultation and inspirational appeal has significant positive relationships with the bases of power such as expert and referent.

For the purpose of this study, the researchers have chosen Yukl and his colleagues (Yukl \& Falbe, 1990; Yukl \& Tracey, 1992) downward influence tactics. It is among the most popular downward influence used in research. In fact, Yukl and his colleagues model was based on Kipnis et al. (1980) influence styles. This work leads them to identify the primary tactics leaders used in downward direction is defined in Table 1.

\subsection{Leadership Styles}

Past researchers have studied on transactional leadership as the core component of effective leadership behavior in organizations prior to the introduction of transformational leadership theory into the literature (Bass, 1985; Burns, 1978; House, 1977). Transactional leadership is based on exchange relationship where subordinates agreed with, accepted, or complied with the superior in exchange for rewards, resources or the avoidance of disciplinary action (Podsakoff, Todor \& Skov, 1982; Podsakoff, MacKenzie, Moorman \& Fetter, 1990). Previous research has shown transactional contingent reward style leadership to be positively related to followers' commitment, satisfaction, organizational citizenship behavior and performance (Bycio, Hackett \& Allen, 1995; Hunt \& Schuler, 1976; Podsakoff, Todor, Grover \& Huber, 1984; Goodwin, Wofford \& Whittington, 2001).

More recently, there are many empirical work on transformational leadership focused on the extent to which transformational leadership augments the effect of transactional leadership in explaining various outcomes. For example, leader effectiveness (Hater \& Bass, 1988), subordinate satisfaction (Seltzer \& Bass, 1990) and subordinate effort (Bass, 1985), and little is known about the transformational-transactional leadership and the influence tactics although there are several writers highlighted the important of studying power and influence processes (Bass, 1990; Hollander \& Offermann, 1990; Yukl, 1989). These recommendations seem particularly relevant for transformational leadership research as the literature suggests that (1) the pursuit of visionary influence objectives is a distinguishing feature of transformational leadership, (2) transactional and transformational leaders employ different kinds of influence strategies or tactics to obtain follower conformity, and (3) transactional and transformational leaders elicit different patterns of follower conformity (Kelman, 1958; Howell, 1988; Tichy \& Devanna, 1986). This new genre of leadership advocates that transformational leaders can motivate followers to perform beyond the normal call of duty. There is also considerable empirical support that such leaders produce leadership effects such as high follower motivation, satisfaction, and commitment.

\subsection{Organizational Contextual Variables}

Several researchers have attributed the influence tactics to various factors e.g. span of control (Morris, Steers \& Roch, 1979) and organizational structure (Weber, 1946; Crozier, 1964).

\subsubsection{Span of Control}

Span of control is the number of subordinates reporting to a superior. If the span is narrow, manager will have few underlings. Narrow span will provide closer supervision and tighter "boss-oriented" controls; thus resulting in tall, hierarchical structure (Likert \& Likert 1976; Tannenbaum 1968). On the other hand, wider spans will generally entail more responsibility be given to subordinates, thereby making the job more fulfilling. Thus, span of control can be an important variable in the superior-subordinate exchange relation. Moreover, studies by Morris, Steers and Roch (1979) shows that superior span of control contributes to the explained variance in influence styles. Extending this argument, it is also presupposed that supervisory span will have influence to the way manager exercising influence tactics. 


\subsubsection{Organizational Structure}

The study of organizational structure relies on the differentiation of position, formulation of rules and procedures, and prescriptions of authority (Weber, 1946). In this study, structure is conceptualized on a mechanistic-organic continuum. Crozier (1964) suggests that an organization stresses rules, policies, and procedures will lead to rigidity and inflexibility develops an elaborate control system backed by a centralized staff, this is called "mechanistic" or "bureaucratic". Crozier (1964) called the opposite type "organic". Organic structure is to be seen as the dominant form of structural design in the near future. Studies by Wells (1990) and Ferris, Duleboun, Flink, George-Falry, Mitchell and Matthew (1997) stated that structure might affect the influence styles. Their findings show that superior tends to favor inspirational appeal and consultation approach when the structure is organic.

\subsection{Subordinates' Competency Level}

Superior exercises of influence styles can be affected by subordinates' competence level. If subordinate competence level is high, superior may use soft tactics such as inspirational appeal and consultation (Snyder \& Bruning, 1985). On the other hand, assuming subordinates' competency is low, superior may be expected to use hard tactics like pressure (Salam, 1998). This could be due to superior who lack confidence in their own capabilities may feel threatened by highly competent subordinates.

\subsection{Role Ambiguity}

Role ambiguity occurs when employees are not certain of how to go about to perform a given roles or tasks. This could due to the management have not clearly identified the responsibilities of the job (Thomas, 1976). Uncertainty regarding one's job responsibilities creates an environment that fosters influence attempts because of the unclear connections among effort, performance, and desired outcomes (Madison, Allen, Porter, Renwick \& Mayes, 1980; Parker, Dipboye \& Kackson, 1995). Similarly, when employees experience task ambiguity due to their uncertainty of task responsibilities, a favourable situation for influence attempts is created (Hickson, Hinings, Lee, Schneck \& Pennings, 1971). Thus, superior should use inspirational and consultation method to convince subordinates to perform their roles constructively, despite the lack of clarity in their roles.

\subsection{Satisfaction with Supervision}

Satisfaction with supervision has received extensive attention in organizational research (Locke, 1976). Work satisfaction is an important workplace construct and one that is of concern for effective management. Thus, numerous research findings suggest that influence management style is related to various aspects of employee satisfaction are of interest and represent an important extension to the job satisfaction literature. The amount of supervision and direction given to the subordinates will increase their satisfaction with supervision. Conversely, many studies recorded that supervision to the extent that the superior exercises pressure tactics is found to have a negative impact on the subordinates' satisfaction (Kahn, Wolfe, Quinn, Snoeck \& Rosenthal, 1964; Likert \& Likert, 1967).

\subsection{Organizational Citizenship Behaviour (OCB)}

Bateman and Organ (1983) introduced the construct of OCB, drawing upon concepts of super role behaviors presented by Katz and Kahn (1966). Examples of employees OCB include, accepting extra duties and responsibilities at work, work overtime when needed, and helping subordinates with their work (Masterson, Lewis, Goldman \& Taylor, 1996; Organ, 1988). Determining why individuals engage in OCB has occupied a substantial amount of research attention in both organizational behavior and social psychology (Brief \& Motowidlo, 1986; McNeely \& Meglino, 1994). Most research on OCB as focused on individual antecedents. For example, researchers have suggested that there is a relationship between OCB and satisfaction (Bateman \& Organ, 1983) commitment (O'Reilly \& Chatman, 1986), perceptions of fairness (Folger, 1993; Martin \& Bies, 1991; Moorman et al., 1993; Tepper \& Taylor, 2003), perceptions of pay equity (Organ, 1998).

\section{Hypothesized Relationship}

\subsection{Organizational Structure and Downward Influence Tactics}

Except for the perceptual study by Madison, Allen, Porter, Renwick and Mayes (1980), there was no major empirical studies been done to investigate the effects of organizational context on the use of downward influence tactics in organizations. Thus, this study was designed in an attempt to examine the exercise of downward influence in work settings on the contextual effects of organizations on superior's use of influence tactics in dealing with subordinates. Burns and Stalker (1961) define organic structure as horizontal specialization and there are few rules being emphasized in the organization. If the organizational structure is such that organic is prevalent, then superior will have a greater tendency to employ inspirational appeal, consultation, ingratiation and rational persuasion in their downward influence attempts. It can be expected that superior's choice of influence tactics will be a function of the organizational context in which the influence attempt occurs. Consistent with the contextual approach to organizational behavior research (Bass, 1981; Herman \& Hulin, 1972; Rousseau, 1978), this study hope to find the link between organizational 
characteristics to individual responses. Subordinate competence level i.e. the extent to which subordinates is effective in doing their work is suspected to mediate the relationship between organizational structure and downward influence tactics. Past research has shown that these variables tend to be correlated (Payne \& Pugh, 1976). Accordingly, the following hypotheses are advanced:

Hypothesis 1a: Organic structure is positively associated with inspirational appeal, consultation, ingratiation and rational persuasion and negatively associated with pressure and exchange tactics.

Hypothesis 1b: Organic structure is negatively associated with pressure and exchange tactics. Role ambiguity will mediate this relationship such that the negative relationship between organic structure and pressure and exchange tactics will be weaker among employees experiencing high levels of role ambiguity compared with those reporting low levels of role ambiguity.

Hypothesis 1c: $\quad$ Organic structure is positively associated with inspirational appeal, consultation, ingratiation and rational persuasion. This relationship is mediated by the subordinate's competence level.

\subsection{Span of Control and Downward Influence Tactics}

On the other hand, superiors who possess wider span of control are more likely to influence subordinates in a more formalized, impersonal manner, using warnings and punishments (Kipnis \& Cosentino 1969; Kipnis \& Lane 1962). In addition, as spans of control increase, managers are found to more autocratic (Heller \& Yukl, 1969). As such, the following hypotheses are predicted:

Hypothesis 1d: $\quad$ Wider span of control is positively associated with exchange and pressure tactics but negatively associated with inspirational appeal, consultation, and rational persuasion.

\subsection{Leadership Styles and Downward Influence Tactics}

Burns (1978) and Bass (1985) have conceptualized the transactional and transformational leadership. Burns (1978) viewed transformational leadership as a process of activating followers' higher level needs by inspiring higher ideals and raising moral consciousness. Burns contrasted the heroic, agent of transformational leadership with the transactional leader, who invokes exchange processes in order to satisfy followers' self-interests (i.e., exchanging pay and other benefits for follower effort). According to Bass (1985), transactional leadership enhances the likelihood that followers will display expected levels of performance (by providing desired rewards contingent on acceptable performance and by clarifying role expectations when followers do not met performance standards). Transformational leadership involves heightening follower motivation to accomplish goals that exceed expectations by instilling pride and confidence, communicating personal respect, facilitating creative and critical thinking, and providing inspiration. However, transformational leaders frequently employ transactional behaviors to accomplish routine tasks (Avolio \& Bass, 1988).

It may be predicted that transactional leaders frequently exert influence by offering to reciprocate or exchange favours (i.e., exchange tactics). However, it may be expected that transformational leaders employ more personally involving influence tactics (e.g., personal appeals, inspirational appeals, consultation, and rationality) than their transactional counterparts (Falbe \& Yukl, 1992; Yukl, 1998). There are several reasons for suspecting an association between influence tactics and transformational leadership. Leaders' behaviours that inspire others to change their beliefs and values (Bass, 1997) reminiscent of inspirational appeal. Inspirational appeals refer to the use of values and ideals to arouse an emotional response in the subordinates (Yukl, 2002; Yukl \& Seifert, 2002). The request is presented in such a way that it resonates with the subordinate's needs, values, and ideals. Inspirational appeals are known to be an effective tool to raise the subordinate's enthusiasm towards the request (Yukl et al., 1996). Transformational leader inspires and challenge subordinates to achieve beyond their self-expectations by raising their self-confidence (Bass, 1997, 1998). Thus, inspirational appeals tactic is expected to be associated with transformational leadership who often communicate with vivid imagery and symbols in a way that generates enthusiasm (Yukl, 2002).

In addition, transformational leader should be more likely to influence subordinates by getting them personally involved and committed to a project through consultation tactics, including participate them to contribute and suggest ways to improve a proposal or help plan an activity (Yukl, 2002; Yukl e al., 1996; Yukl \& Seifert, 2002; Yukl \& Tracey, 1992). Furthermore, the use of rational persuasion is associated with transformational leadership (Caldwell \& Burger, 1997; Bass, 1997, 1998). Rational persuasion aims at encouraging subordinates to think critically, rationally or creatively and to express their ideas. When using rational persuasion tactic, transformational leaders create an environment that encourages the reframing of problems through the use of explanations, factual evidence, and logical arguments (Yukl, 2002; Yukl \& Seifert, 2002). Rational persuasion is widely used (Aguinis et al., 1994; Yukl \& Falbe, 1990; Yukl \& Seifert, 2002) by transformational leader to obtain subordinate's commitment to a request (Yukl et al., 1996; Yukl \& Tracey, 1992; Kelloway \& Barling, 2000) regardless of whether the target is a subordinate, peer, or superior.

Moreover, transformational leader who take into account individual subordinate's accomplishment by praising and 
flattery to make them feel liked by the superior can show a positive effects on work outcomes (Higgins et al., 2003). Ingratiation involves flattery and favour doing enhancing managerial liking of the subordinate. In addition, superior reacts differently to different subordinates' competence level. Lowin and Craig (1968) have documented in their field experiment that supervisors reacted more warmly, permissively, and collegially to a subordinate when the latter worked efficiently. Greene (1975) in a longitudinal study concluded that managers initiated more structure and showed less consideration for sub-part performers. Therefore, it was hypothesized that;

Hypothesis 2a: Transformational leadership is positively associated with inspirational appeal, consultation, rational persuasion and ingratiation. This relationship is mediated by the subordinate's competence level.

Hypothesis 2b: Transformational leadership is negatively associated with pressure and exchange tactics. This relationship is mediated by the subordinate's competence level.

\subsection{Leadership styles and Organizational Citizenship Behavior}

We tested a hypothesis about the relationships between both transformational and transactional leadership and organizational citizenship behavior (Podsakoff et al., 1990). Transformational leadership has been consistently linked to followers' higher level of OCB (Geyer \& Steyrer, 1998; Howell \& Avolio, 1993; Lowe, Kroeck \& Sivasubramaniam, 1996; Onnen, 1987). On the other hand, transactional leadership has been negatively link to follower low level of OBC (Bass \& Avolio, 1990).

Graham (1988) has suggested that the most important effects of transformational leadership behavior should be on extra-role behaviors that exceed the requirements of in-role expectations. These extra role behaviors are best articulated by the OCB construct developed by Organ (1988); Deluga, (1995), Organ and Konovsky (1989), Podsakof et al. (1990). OCB refers to the behavior of an employee that is discretionary, not rewarded or recognized in an explicit way the organization, and tends to promote efficient and effective functioning of the organization (Organ, 1988). Results of research show transformational leadership behavior to have a positive relationship with OCB (Graham, 1988; Podsakoff et al., 1990; Whittington, 1997). Although the relationship between transactional leadership and OCB has not been empirically examined, Graham (1988) suggests that the instrumental compliance to obtain rewards required by transactional leadership may suggest a reduction in OCB when working for a transactional leader.

OCB is behavior, largely discretionary, and seldom included in formal job description. Transformational leaders motivate followers by getting them to internalize and prioritize a larger collective cause over individual interests. Individuals who are intrinsically motivated to fulfill a collective vision without expecting immediate personal and tangible gains may be inclined to contribute toward achieving the shared workplace goal in ways that their roles do not prescribe. These individuals make these contributions because their senses of self-worth and self-concepts are enhanced in making these contributions. Individuals for whom this link between the interests of self and others has not been established are less likely to make largely discretionary, non-tangibly rewarded contributions. A positive association between transformational leadership and OCB is expected and has been supported empirically (e.g., Podsakoff et al., 1990). Thus, the hypothesis is stated as follows:

Hypothesis 2c: Transformational leadership style is positively correlated with OCB whereby, transactional leadership style is negatively correlated with OCB

\subsection{Leadership Styles and Satisfaction with Supervision}

Among determinants of job satisfaction, leadership is viewed as an important predictor and plays a central role. Leadership is a management function, which is mostly directed towards people and social interaction, as well as the process of influencing people so that they will achieve the goals of the organization (Skansi, 2000). Numerous studies carried out in several countries showed that there is a positive correlation between leadership and the job satisfaction (Seo, et al. 2004; Vance \& Larson, 2002; Chiok Foong Loke, 2001; Martin, 1990; Dunham \& Klafehn, 1990; Stordeur et al., 2000; Hespanhol et al., 1999; Lowe et al., 1996; Berson \& Linton, 2005; Morrison, 1994; Mosaderghrad, 2003a). As such the following hypothesis is predicted.

Hypothesis 2d: Transformational leadership style is positively correlated with satisfaction with supervision, whereas transactional style is negatively correlated with satisfaction with supervision.

\subsection{Structure and Outcomes}

In relation to organizational context, research by Meadows (1980) concluded that organic structure is positively related to satisfaction of higher order needs, but mechanistic structure is associated with their frustration. This statement is also supported by Rahman and Zanzi (1995) in their study which confirms organic structure is associated with greater job satisfaction with supervision and OCB. Considering these past findings, the following hypotheses are suggested as follows:

Hypothesis 3a: $\quad$ Organic structure has direct and positive effect on the satisfaction with supervision. 
Hypothesis 3b: Mechanistic structure has direct and negative effect on the satisfaction with supervision.

Hypothesis 3c: Organic structure has direct and positive effect on the organization citizenship behaviour.

\subsection{Downward Influence Tactics and Outcomes}

Organizational influence researchers (e.g. Kipnis, Schmidt \& Wilkinson, 1980; Kipnis \& Schmidt, 1988; Yukl \& Falbe, 1990; Yukl, Lepsinger \& Lucia, 1993; Yukl \& Tracey, 1992; Hinkin \& Schriesheim, 1990; Pfeffer 1981) generally assert that superior who exhibits inspirational appeal, consultation, ingratiation and rational persuasion tactics are more prone to foster a cordial dyadic relationships among superiors and subordinates. These tactics are related to an effective influence management.

Conceptual and empirical research on influence tactics and OCB have flourished concurrently but only recently have their conceptual overlaps in behavioural and motive content been pointed out (e.g., Bolino, 1999; Eastman, 1994; Ferris, Bhawuk, Fedor \& Judge, 1995). Because of the past investigation of influence tactics and OCB separately, little is known about their level of distinctiveness. This omission represents a research need because both of these categories of behaviour are common within organizations and both have been found to be associated with supervisor-subordinate relationship quality and important organizational outcomes.

The current study was designed to address this gap in the literature by evaluating whether or not supervisor downward influence tactics and OCB are distinct constructs and whether they have a differential impact on superior-subordinate relations. Researchers have found that influence tactics are often used by superiors as a means of obtaining personal goals, promoting their own self interest, exercising social control, and changing the behaviour of others (Ferris \& Judge, 1991; Ferris, Russ \& Fandt, 1989; Kipnis et al., 1980; Barry \& Watson, 1996). The successful used of these tactics tend to be able to reduce resistance by the subordinates' (Pfeffer, 1981; Tedeschi \& Melburg, 1984). Initial conceptual and theoretical work in influence tactics research suggested that ingratiation by superior would enhance supervisor-subordinate relationship (Jones, 1964; Tedeschi \& Melburg, 1984). Ingratiation tactics used by superior to impress their employees with the objective of being better liked (Kipnis, Schmidt \& Wilkinson, 1980; Tedeschi \& Melburg, 1984; Wayne \& Liden, 1995). These tactics include flattery, favour-doing, emphasizing what they have in common with their subordinates and de-emphasizing their differences (Krone, 1992). Research has demonstrated that these tactics are effective in gaining positive outcomes from the subordinates.

On the other hand, researchers have generally maintained that OCB demonstrated by employee arises from a sense of obligation and from personality traits (Bolino, 1999). Social exchange theory is the basis for arguing this behavior (Niehoff, 2000). According to Blau (1964) and Organ (1988) the employment relationship engenders feelings of personal obligation when subordinates are treated well by superiors feel obligated to discharge their obligation by engaging in extra-role behaviours directed at helping others and the organization. Several studies on the inspirational appeal and consultation and rational persuasion tactics show consistent results in subordinates' satisfaction with supervision and OCB (Kipnis \& Schmidt, 1988; Schriesheim \& Hinkin 1990). Likewise, other studies recorded that superior uses pressure and exchange tactics are linked to negative effect on subordinates' satisfaction with supervision and OCB (Yulk \& Falbe, 1990; Yukl \& Tracey, 1992).

Thus, it can be hypothesized that:

Hypothesis 4a: Superior's use of inspirational appeal, consultation, ingratiation and rational persuasion has direct and positive effect on the subordinates' satisfaction with supervision.

Hypothesis 4b: Superior's pressure tactic and exchange tactic have negative effect on the subordinates' satisfaction with supervision.

Hypothesis 4c: $\quad$ Superior's inspirational appeal, consultation, ingratiation and rational persuasion have direct and positive effect on organization citizenship behavior.

Hypothesis 4d: Superior's pressure tactic and exchange tactic have negative effect on organization citizenship behavior

\section{Methodology and Research Design}

\subsection{Sampling Design}

The sampling population is generated from the master list of factories registered with the Federation of Malaysian Manufacturers (FMM). We include manufacturing companies with the number of employees greater than 30 as our sample because this number chosen can reflect a more formalized structure and system of supervision that likely to exist and functioning. The sample size would be 350 respondents from executives, managers and professionals in Malaysian manufacturing companies to answer the survey questionnaires as they represent a group of more educated people who are more aware of the types of influence tactics used by their superiors. The stratified random sampling procedure will be used in selecting samples from the large database. 


\subsection{Research Instruments}

Each of the measurements of relevant constructs was discussed here.

4.2.1 Downward Influence Tactics

Yukl's 44-item Influence Behaviour Questionnaire-2000 (IBQ-2000)

\subsubsection{Organization Structure}

Organization structure was represented a 7 item scale which measures organicity, i.e. the extent to which organizations are structured as organic versus mechanistic entities. This seven-point Likert-type scale was also developed by Khandwalla (1977) and later used by Covin and Slevin (1989) and Low (2005).

\subsubsection{Leadership}

Transformational and transactional leadership were measured by using the German translation of the (MLQ Form 5X Short; Bass \& Avolio, 1995) by Felfe (2006). As the four single components of transformational leadership usually show high intercorrelation $(r=.83$ on average; Bass \& Avolio, 2000). We measured leadership as unidimensional concept (see Hambley, Kline, \& O’Neill, 2005; Walumba et al., 2004). The participants were asked to rate their superior's leadership behavior on a seven-point Liker scale (ranging from "never" to "almost always"). Since the leaders themselves were asked to assess their leadership style, we used a version for self-evaluation that had already been used in previous studies (Felfe, 2003; Goihl, Tartler \& Kroger, 2001; Liepmann \& Goihl, 2001). Cronbach's alphas for this scale were .78 for transformational leadership and .62 for transactional leadership.

\subsubsection{Span of Control}

Span of control is a measure of the total number of person being supervised by a superior.

\subsubsection{Satisfaction with Supervision}

The instrument used to measure satisfaction with supervision is the updated version of the original Job Descriptive Index (JDI; Smith at el., 1969) which was later revised by Roznowski (1989).

\subsubsection{OCB}

OCB scale was measured using a 6-item scale for altruism and an 8-item scale for compliance developed by Smith, Organ and Near (1983). The scale measures high and low of OCB. Respondents indicated the frequency in which they had engaged in the various citizenship behaviours. Responses were made on a 7-point scale. The coefficient alpha was .76 for altruism and .66 for compliance.

\subsubsection{Role Ambiguity}

The six-item scale developed by Rizzo, House and Lirtzman (1970) was used to measure role ambiguity. This scale was selected because it is the most commonly used to measure role ambiguity in management literatures (Jackson \& Schuler, 1985). Individual scale items were evaluated on a 7-point Likert-type scale. The scale was reverse coded such that higher number responses reflect greater level of role ambiguity.

\subsubsection{Subordinates' Competence Level}

Wagner and Morse's (1975) self-report measure of individual sense of competence was used to measure employee task competence in lieu of a more direct measure of competence level. Thirteen items were extracted from their larger pool of items for used based upon their factor loadings as reported in Wagner and Morse (1975). A sample item stated, "I honestly believe I have all the skills necessary to perform this task well." All items were scaled on 7-point agree-disagree rating scales. Evidence pertaining to the reliability and predictive validity of this measure is located in several sources (Morse, 1976; Tharenou \& Harker, 1984; Wagner \& Morse, 1975).

\subsection{Data Analysis Procedure}

The main statistical techniques used will be the Path Analysis. Other statistical analysis to be employed is correlational analysis, moderated regression analysis, and analysis of variance (ANOVA).

\section{Benefit and Implications of the Proposed Research}

There are several specific implications expected from the present study. First, the research suggests that when the superior has a choice in the influence styles he/she emphasizes to achieve greater satisfaction with his/her supervision. For example influence attempt such as inspirational appeal, consultation, rational persuasion, ingratiation tactics are expected to be more favourable than exchange and pressure tactic. Second, in the selection of superior to lead a division of work, especially when the work group is highly experience and skilled, it is expected that certain characteristics or ability will assist in the management of such work group effectively. It may affect the influence style and the outcomes in a direct or indirect way.

Interaction or mediation effect of role ambiguity and subordinates' competence level are investigated and expected to 
shed light on how the variable provide direct and indirect effects on downward influence tactics and the outcomes. In an attempt to solicit subordinate super-ordinate effort in the organization, both satisfaction and OCB are included in the outcome variables of the study. Relationships must exist to highlight the relevant contextual and influence tactics that promotes such behaviour in the organization and this will have great practical significance.

\section{References}

Ansari, M. A. \& Kapoor, A. (1987). Organizational context and upward influence tactics. Organizational Behaviour and Human Decision Processes, 40, 39-49.

Bass, B. M. \& Avolio, B. J. (1990). Transformational leadership: A response to critiques. In Chimers, M. M. \& R. Ayman, (Eds.), Leadership Theory and Research: Perspectives and Directives (pp 49-80). New York: Academic Press.

Bass, B. M. \& Avolio, B. J. (1995). Multifactor leadership questionnaire for research. Pa Alto, CA: Mind Garden, Inc.

Bass, B. M. (1981). Stogdill's handbook of leadership $\left(2^{\text {nd }} E d\right)$. New York: Free Press.

Bass, B. M. (1985). Leadership and performance beyond expectations. Free Press, New York.

Bass, B. M. (1990). From transactional to transformational leadership: Learning to share the vision. Organizational Dynamics, 18(3), 19-6.

Bass, B. M. (1997). Does the transactional-transformational leadership paradigm transcend organizational and national boudaries? American Psychologist, 52.

Bass, B. M. (1998). Transformational leadership: Industry, military, and educational impact. Mahwah, NJ: Erlbaum.

Bateman, T. S. \& Organ, D. W. (1983). Job satisfaction and the good soldier: The relationship between affect and employee "citizenship". Academy of Management Journal, 26, 587-595.

Berson, Y. \& Linton, J. D. (2005). An examination of the relationships between leadership style, quality, and employee satisfaction in R\&D versus administrative environments. $R \& D$ Management, 35(1), 51-60.

Bolino, M. C. \& Turnley, W. H. (2003). "Going the extra mile: Cultivating and managing employee citizenship behavior". Academy of Management Executive, 17(4), 60-71.

Brief, A. P. \& Motowidlo, S. J. (1986). Prosocial organizational behaviours. Academy of Management Review, 11, 710-725.

Burns, J. M. (1978). Leadership. Harper and Row, New York, NY.

Burns, T. \& Stalker, G. M. (1961). The management of innovation. London: Tavistock.

Bycio, P., Hackett, R. D. \& Allen, J. S. (1995). Further assessments of Bass's (1985) conceptualization of transactional and transformational leadership. Journal of Applied Psychology, 80, 468-478.

Case, T., Dosier, L., Murkison, C. \& Keys, B. (1988). How managers influence superiors: A study of upward influence tactics. Leadership and Organizational Development Journal, 19(4), 25-31.

Chiok, Foong, Loke. (2001). Leadership behaviours: effects on job satisfaction, productivity and organizational commitment. Journal of Nursing Management, 9(4), 191-204.

Deluga, R. J. (1995). The relationship between trust in the supervisor and subordinate organizational citizenship behavior. Military Psychology, 7, 1-16.

Dunham, J. \& Klafehn, K.A. (1990). Transformational leadership and the nurse executive. Journal of Nursing Administration, 20(4), 28-34.

Erez, M. \& Rim, Y. (1982). The relationship between goals, influence tactics, and personal and organizational variables. Human Relations, 35, 871-878.

Erez, M., Rim, Y. \& Keider, I. (1986). The two sides of the tactics of influence. Agent vs. Target. Journal of Occupational Psychology, 59, 25-39.

Falbe, C. M. \& Yukl, G. (1992). Consequences for managers of using single influence tactics and combinations of tactics. Academy of Management Journal, 35, 638-652.

Ferris, G. R., Dulebohn, J. H., Frink, D. D., George-Falvy, J., Mitchell, T. R. \& Matthews, L. M. (1997). Job and organizational characteristics, accountability, and employee influence. Journal of Managerial Issues, 20(2), 59-71.

Ferris, G. R., Russ, G. S. \& Fandt, P. M. (1989). Politics in organizations. In R. A. Giacalone \& P. Rosenfeld (Eds.), Impression management in organization (pp. 143-170). Hillsdale, NJ: Erlbaum.

Folger, G. (1993). Justice, motivation, and performance beyond role requirements. Employee Responsibilities and 
Rights Journal, 6(3), 239-248.

Frone, M. R. (1990). Intolerance of ambiguity as a moderator of the occupational role stress-strain relationship: A meta-analysis. Journal of Organizational Behaviour, 3(4), 309.

Geyer, L. \& Steyrer, J. M. (1998). Transformational leadership and objective performance in banks. Applied Psychology: An International Review, 47, 97-420.

Goodwin, V. L., Wofford, J. C. \& Whittington, (2001). A theoretical and empirical extension to the transformational leadership construct. Journal of Organizational Behaviour, 22, 759-774.

Graham, J. (1988). Transformational leadership: Fostering follower autonomy, not automatic followership. In J. Hunt, B. Baglia, H. Dachler, C. Schriesheim (Eds.), Emerging Leadership Vistas. Lexington Books: Lexington, MA; pp 73-79.

Greene, C. N. (1975). The reciprocal nature of influence between leader and subordinate". Journal of Applied Psychology, 60, 187-193.

Hater, J. J. \& Bass, B. M. (1988). Superiors' evaluations and subordinates' perceptions of transformational and transactional leadership. Journal of Applied Psychology, 73, 695-702.

Heller, F. \& Yukl, G. (1969). Participation, Managerial Decision-Making and Situational Variables. Organization Behavior and Human Performance. 4, 227-241.

Herman, J. B. \& Hulin, C. L. (1972). Studying organizational attitudes from individual and organizational frames of reference. Organizational Behavior and Human Performance, 8, 84-108.

Hickson, D. J., Hinings, C. R., Lee, C. A., Schoeck, R. E., \& Pennings, J. M. (1971). A strategic contingency theory of intraorganizational power. Administrative Science Quarterly, 6, 216-229.

Hollander, E. \& Offermann, L. R. (1990). Power and leadership in organizations: Relationship in transition. American Psychologist, 45, 179-189.

House, R. (1977). A 1976 theory of charismatic leadership. In J.G. Hunt \& L.L. Larson (Eds.), Leadership on the cutting edge (pp. 189-207). Carbondale, IL: Southern Illinois University Press.

Howell, J. M. \& Avolio, B. J. (1993). Transformational leadership, transactional leadership, locus of control, and support for innovation: Key predictors of consolidated-business-unit performance. Journal of Applied Psychology, 78, 891-902.

Hunt. J. G. \& Schuler, R. S. (1976). Leader reward and sanctions behavior in a public utility: What difference does it make? Working paper, Southern Illinois University.

Kahn, R. L., Wolfe, D. M., Quinn, R. P., Snoeck, J. D. \& Rosenthal, R. A. (1964). Organizational stress. Studies in role conflict and ambiguity, New York: Wiley.

Kaplan, R. E. (1986). Trade routes: “The manager's network of relationship. Organizational Dynamics, 37-52.

Katz, D. \& Kahn, R. L. (1966). The social psychology of organizations. New York: Wiley.

Kelman, H. C. (1958). Compliance, identification and internalization: Three processes of opinion change. Journal of Conflict Resolution, 2, 51-60.

Kipnis, D. \& Cosentino, J. (1969). Use of leadership powers in industry. Journal of Applied Psychology, 53, $460-466$.

Kipnis, D. \& Lane, W.P. (1962). Self confidence and leadership. Journal of Applied Psychology, 46, 291-295.

Kipnis, D. \& Schmidt, S.M. (1988). Upward influence styles: Relationship with performance evaluations salary and stress. Administrative Science Quarterly, 33, 528-542.

Kipnis, D., Schmidt, S. M. \& Wilkinson, I. (1980). Intraorganizational influence tactics: Explorations in getting one's way. Journal of Applied Psychology, 65, 440-452.

Krone, K. J. (1992). A comparison of organizational, structural and relationship effects on subordinates' upward influence choice. Communication Quarterly, 40, 1-15.

Lamude, K. G. (1994). Supervisors' influence tactics for handling managers' resistance. Psychological Reports, 75, 371-374.

Likert, R. \& Likert, J. G. (1976). New ways of managing conflict. New York: McGraw-Hill.

Locke, E. A. (1976). The nature and causes of job satisfaction. In M. Dunnette (Ed.), Handbook of Industrial and Organizational Psychology, Chicago, IL, pp 1297-1350.

Lowe, K. B., Kroeck, K. G. \& Sivasubramaniam, N. (1996). Effectiveness correlates of transformational and transactional leadership: A meta-analytic review of the MLQ literature. Leadership Quarterly, 1 7, 385-42. 
Lowin, K. B. \& Craig, J. (1968). The influence of level of performance on managerial style: An experimental object-lesson in the ambiguity of correlational data. Organizational Behaviour and Human Performance, 3, 440-458.

Madison, D. L., Allen, R. W., Porter, L. W., Renwick, P. A. \& Mayes, B. T. (1980). Organizational politics: An exploration of angers' perception. Human Relations, 33, 79-100.

Martin, C. L. \& Bies, R. J. (1991). Just laid off, but still a good citizen? Only if the process is fair”. Annual Meeting of the Academy of Management, 6(3), 227-238.

Masterson, S. S., Lewis, K., Goldman, B. \& Taylor, M. S. (1996). Integrating justice and social exchange: The differing effects of fair procedures and treatment on work relationships. Academy of Management Journal, 43, 738-748.

Moorman, C., Rohit, D. \& Zaltman, G. (1993). Factors affecting trust in marketing research relationships. Journal of Marketing, 57, 81-101.

Morrison, E. W. (1994). Role definitions and organizational citizenship behavior: The importance of the employee's perspective. Academy of Management Journal, 37, 1543-1567.

Motowidlo, S. M. (2003). Job performance, in W. C. Borman, D. R. Ilgen \& R. Klimoski, (Eds.), Comprehensive Handbook of Psychology, Vol. 12: Industrial and Organizational Psychology. New York: Wiley.

Mowday, R. T. (1978). The exercise of upward influence in organizations". Administrative Science Quarterly, 23, 137-156.

Niehoff, B. P. (2000). A motive-based view of organizational citizenship behaviours: Applying an old les to a new class or organizational behaviours. Proceedings, Midwest Academy of Management.

Organ, D. W. \& Konovsky, M. (1989). Cognitive versus affective determinants of organizational citizenship behavior. Journal of Applied Psychology, 74, 157-164.

Organ, D. W. (1988). Organizational citizenship behavior: The good soldier syndrome. Lexington, MA: Lexington Books.

Pfeffer, J. (1981). Power in organizations. Boston: Pitman.

Podsakoff, P. M., MacKenzie, S. B. Morrman, R. H. \& Fetter, R. (1990). Transformational Leader Behaviors and their Effects on Follower's Trust in Leader Satisfaction, and Organizational Citizenship Behaviors. Leadership Quarterly, 1, 107-142.

Podsakoff, P. M., Todor, W. D. \& Skov, R. (1982). Effects of Leader Contingent and Non Contingent Reward and Punishment Behaviours on Subordinate Performance and Satisfaction. Academy of Management Journal, 22 , 810-821.

Podsakoff, P. M., Todor, W. D., Grover, R. A. \& Huber, V.L. (1984). Situational moderators of leader reward and punishment behaviors: Fact or fiction? Organizational Behavior and Human Performance, 34(1), 1-63.

Rahman, M. \& Zanzi, A. (1995). A Comparison of Organizational Structure, Job Stress, and Satisfaction in Audit and Management Advisory Services in CPA Firms. Journal of Managerial Issues, 17(3), 290.

Rizzo, A. \& Mendez, C. (1988). Making things happen in organization: Does gender make a difference? Public Personnel Management, 1, 9-22.

Rousseau, D. M. (1978). Characteristics of departments, positions, and individuals: Contexts for attitudes and behavior. Administrative Science Quarterly, 23, 521-540

Ruello, S. H. (1973). Transferring managerial concepts and techniques to operating management. Advanced Management Journal.

Schilit, W. K. \& Locke, B. (1982). A study of upward influence in organizations. Administrative Science Quarterly, 27, 304-316.

Schmidt, S. M. \& Kipnis, D. (1984). Manager's Pursuit of Individual and Organizational Goals. Human Relations, 37, 781-794.

Schriesheim, C. A., \& Hinkin, T. R. (1990). Influence tactics used by subordinates: A theoretical and empirical analysis and refinement of the Kipnis, Schmidt, and Wilkinson Subscales. Journal of Applied Psychology, 759, $246-257$.

Seltzer, J. \& Bass, B. M. (1990). Transformational leadership: Beyond initiation and consideration. Journal of Management, 16(4), 693-703.

Skansi, D. (2000). Relation of managerial efficiency and leadership styles - Empirical study in Hrvatska Elektroprivreda D.D. Management, 5(2), 51-67.

Smith, C. A., Organ, D. W., \& Near, J. P. (1983). Organizational citizenship behavior: Its nature and antecedents. 
Journal of Applied Psychology, 68, 653-663.

Snyder, R. A. \& Bruning, N. S. (1985). Quality of vertical dyad linkages: Congruence of supervisor and subordinate competence and role stress as explanatory variables. Group \& Organization Studies, 10(1), 81.

Stordeur, S., Vandenberghe, C. \& D'hoore, W. (2000). "Leadership styles across hierarchical levels in nursing department". Nursing Research, 49(1), 37-43.

Tadepalli, R. (1991). An empirical investigation of the impact of task conflict and task ambiguity on buyers' role perceptions Journal of Business, 27(3), 251.

Tannenbaum, A. (1968). Control in organizations. McGraw-Hill, New York.

Tedeschi, J. T. \& Melburg, V. (1984). Impression management and influence in the organization. In S.B. Bacharach \& E.J. Lawler (Eds.), Research in the sociology of organizations (Vol. 3, pp. 31-58). Greenwich, CT: JAI Press.

Tepper, B. J. \& Taylor, E. C. (2003). Relationships among supervisors' and subordinates' procedural justice perceptions and organizational citizenship behaviors. Academy of Management Journal. 46(1), 97-05.

Thomas, K. W. (1976). Conflict and Conflict Management. In M.D. Dunnette (Ed.), Handbook of Industrial and Organizational Psychology (pp. 889-935). Chicago: Rand McNally.

Tichy, N. M. \& Devanna, M. A. (1986). The transformational leader. New York: Wiley.

Uyterhoeven, H. (1972). General managers in the middle. Harvard Business Review, 50(92), 75-85

Wayne, S. J. \& Liden, R. C. (1995). Effects of impression management on performance ratings: A longitudinal study. Academy of Management Journal, 38, 232-260.

Weber, M. (1946). From Max Weber: Essays in sociology, in H. H. Gerth and C. W. Mills (Eds.). New York: Oxford University Press.

Wells, G. T. (1990). Influence of organizational structure on nurse manager job satisfaction. Nursing Administration Quarterly, 14, 1-8.

Williams, L. J. \& Anderson, S. E. (1991). Job satisfaction and organizational commitment as predictors of organizational citizenship and in-role behavior. Journal of Management, 17, 601-617.

Yukl, G. (1989). Managerial leadership. A review of theory and research. Yearly Review of Management, 15, 251-289.

Yukl, G. A. \& Falbe, C. M. (1990). Influence tactics in upward, downward, and lateral influence attempts. Journal of Applied Psychology, 75, 132-140.

Yukl, G. A. \& Tracey, B. (1992). Consequences of influence tactics used with subordinates, peers, and the boss. Journal of Applied Psychology, 77, 525-535.

Yukl, G. A. (1998). Leadership in organizations. Englewood Cliffs, NJ: Prentice hall.

Yukl, G. A., Falbe, C. M. \& Youn, J. Y. (1993). Patterns of influence behavior for managers. Group and Organizational Management, 18, 5-28.

Yukl, G., Lepsinger, R. \& Lucia, T. (1993). Preliminary Report on the Development and Validation of the Influence Behavior Questionnaire. In K.E. Clark \& B. Clark (Eds.), The impact leadership (pp. 417-427). Greensboro, NC: Center for creative leadership.

\section{Notes}

Note 1. Proposed Model of Downward Influence Tactics and Interaction

Note 2. Definition of Influence Tactics 
Table 1. Definition of Influence Tactics

\begin{tabular}{|l|l|}
\hline Inspirational Appeals & $\begin{array}{l}\text { The agent makes a request or proposal that arouses target enthusiasm } \\
\text { by appealing to target values, ideals, and aspiration, or by increasing } \\
\text { target self-confidence. }\end{array}$ \\
\hline Consultation & $\begin{array}{l}\text { The agent seeks target participation in planning a strategy, activity, or } \\
\text { change for which target support and assistance are desired, or the agent } \\
\text { is willing to modify a proposal to deal with target concerns and } \\
\text { suggestions. }\end{array}$ \\
\hline Ingratiation & $\begin{array}{l}\text { The agent uses praise, flattery, friendly behaviour, or helpful behaviour } \\
\text { to get the target in a good mood or to think favourably of him or her } \\
\text { before asking for something. }\end{array}$ \\
\hline Rational Persuasion & $\begin{array}{l}\text { The agent offers an exchange of favours, indicates willingness to } \\
\text { reciprocate at a later time, or promises a share of the benefits if the } \\
\text { target helps accomplish a task. }\end{array}$ \\
\hline Pressure & $\begin{array}{l}\text { The agent uses logical arguments and factual evidence to persuade the } \\
\text { target that a proposal or request is viable and likely to result in the } \\
\text { attainment of task objectives. }\end{array}$ \\
\hline
\end{tabular}

Adapted from Yukl \& Falbe (1990) and Yukl \& Tracey (1992)

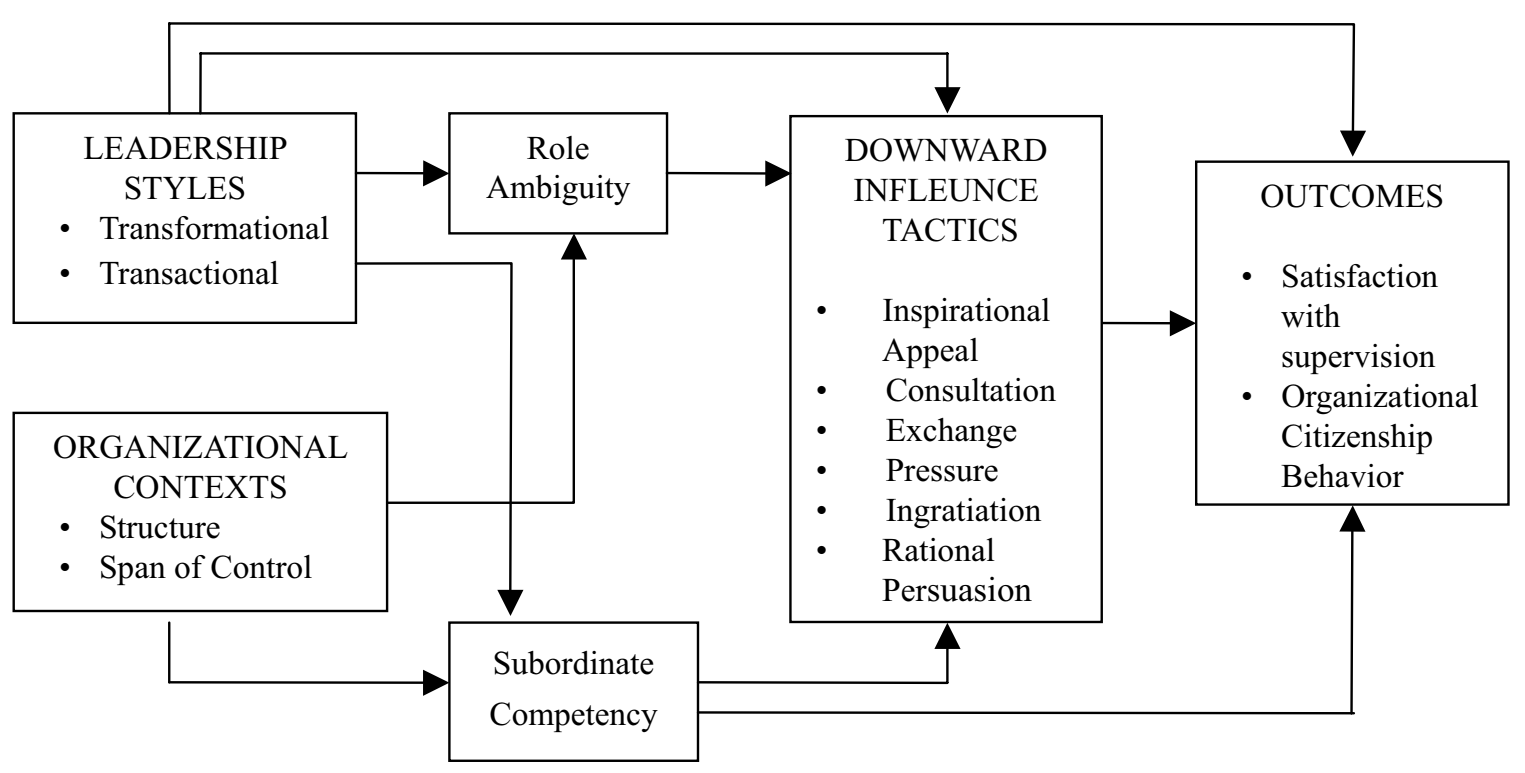

Figure 1. Proposed Model of Downward Influence Tactics and Interactions 